\title{
"Is it Merit or Cultural Capital?" The role of parents during early tracking in Amsterdam and Strasbourg among descendants of immigrants from Turkey
}

Elif Keskiner

Correspondence:

keskiner@fsw.eur.nl

Erasmus University Rotterdam,

Rotterdam, Netherlands

\begin{abstract}
Streaming into educational tracks forms a turning point in the school careers of young people living in the Netherlands and in France. Yet the two countries differ from each other with regards to tracking conditions they provide. This is especially reflected in the experiences of descendants of immigrants from Turkey who access vocational education in higher numbers compared to the children of native parents but also to a greater extent in the Netherlands than in France. While streaming decisions are usually based on meritocratic selection, the current study aims to understand the role of the parents with regard to the tracking decision. Using qualitative interviews with descendants of Turkish immigrants in Amsterdam and Strasbourg, the study shows how the differential role played by parents, during the streaming shapes the tracking outcome of the young people.
\end{abstract}

Keywords: Streaming; Migrant parents; Descendants of immigrants; Educational stratification; Cultural capital

"The official diversification (into tracks or streams) and unofficial diversification (into subtly hierarchized schools or classes, often through the study of modern languages) also help re-create a particularly well-hidden principle of differentiation. The elite students who have received a well-defined sense of place, good role models and encouragement from their families are in a position to apply themselves, at the right moment in the right place; in the good tracks, in the good schools, in the good sections, etc. On the contrary, students who come from the most disadvantaged families, especially children of immigrants, often left to fend for themselves, from primary school on, are obliged to rely either on the dictates of school or on chance to find their way in an increasingly complex universe."

(Bourdieu 1999) (p. 424)

\section{Springer}

(c) 2015 Keskiner. Open Access This article is distributed under the terms of the Creative Commons Attribution 4.0 International License (http://creativecommons.org/licenses/by/4.0/), which permits unrestricted use, distribution, and reproduction in any medium, provided you give appropriate credit to the original author(s) and the source, provide a link to the Creative Commons license, and indicate if changes were made. The Creative Commons Public Domain Dedication waiver (http://creativecommons.org/publicdomain/zero/1.0/) applies to the data made available in this article, unless otherwise stated. 


\section{Introduction}

Over the last two decades, numerous studies have confirmed the link between educational streaming and its consequences in the educational careers of the young people and in the labour market (Tieben and Wolbers, 2010; Van de Werfhorst and Mijs, 2010). Allmendinger defines educational stratification as the designing of education systems to divide pupils into different vocational and academic tracks with varied outcomes and rewards (Allmendinger, 1989). Of the various mechanisms of stratification, or differentiation as Bourdieu refers to it above, streaming into tracks is the most overt and official form. Many education systems stratify the students into distinct tracks or streams. Tracking decisions are officially based on meritocratic selection such as tests and/or student grades and also in some cases on teachers' advice.

Furthermore, countries vary with regards to the nature and degree of tracking in their systems. For example the Dutch and German education systems are usually classified as highly stratified, providing occupation-specific vocational training through a combination of training in school and intensive internship periods (Mueller and Gangl, 2003). In contrast, the French system is classified as less stratified, with different forms of vocational training encompassing both apprenticeship programs and school-based training with modest internship periods leading to the BEP diploma (Mueller and Gangl, 2003).

The differences in the nature of tracking across contexts are reflected in the tracking and educational outcomes of young people, and divergent patterns emerge both across groups and settings. Bol and Van de Werfhorst (2013) have recently illustrated that, while a high level of tracking in a national education system leads to better labour market allocation for young people, it also contributes to unequal educational opportunities, since in such systems the effect of social class background on tracking outcomes is higher. In an international volume studying descendants of immigrants from Turkey, Morocco and ex-Yugoslavian countries in various European cities, Crul et al. (2012) illustrated that descendants of immigrants from Turkey, who form one of the largest groups of immigrant descendants in Europe, are mostly streamed into vocational tracks compared to children of native-born parents, though their presence in vocational tracks varies across countries (Crul et al., 2012). Furthermore, when authors controlled for parental background, they still found descendants of immigrants from Turkey to be more present in the vocational tracks in highly stratified education systems such as Germany and Austria while they attend the academic tracks in higher numbers in less-stratified education systems like in France or in comprehensive systems like that in Sweden (Crul et al., 2012).

In order to account for this divergence, Crul and Schneider (2010) used integration context theory to argue that the earlier the tracking occurs in a system, the less likely it is that descendants of immigrants will access academic tracks. Furthermore, the earlier the descendants of immigrants begin education, the more likely they are to catch up with their peers and make it into academic tracks (Crul et al., 2012). These two explanations also gain extra momentum when the parental background is controlled for.

Focusing on the role of the parents, previous studies have shown that in tracked educational systems the effect of social origin on educational performance tends to be stronger (Brunello and Checchi, 2007; Van de Werfhorst and Mijs, 2010). Crul et al. (2012) argued that countries with early tracking required more assistance from parents compared to less 
stratified education systems. Using data from the TIES Survey, Schnell (2012) illustrated that parental assistance is significant in explaining the educational outcome in the highly stratified Austrian education system compared to France and Sweden.

However, these studies analysed the influence of parental support on the educational outcome, rather than focusing on how parents shape the tracking process per se. As mentioned, the descendants of immigrants from Turkey in the Netherlands and in France present an interesting case study to analyse how young people with similar backgrounds have diverse tracking experiences across different educational systems. Using qualitative interviews, the current article studies the role attributed to parents during tracking decisions among the descendants of Turkish immigrants, comparing their experiences in Amsterdam and Strasbourg. First, the stratification mechanisms, streaming, and school choice will be explained in both settings. Following a descriptive illustration of tracking outcomes using the TIES Survey, the article will focus on young people's accounts on their parents' role during the tracking experience. Based on qualitative evidence, the article juxtaposes how the role of the parents varies across settings leading to differential tracking experiences.

\section{Streaming, school choice and role of parents in France and the Netherlands Streaming}

The Dutch and French education systems form an interesting comparison with regards to their stratification procedures. The highly stratified Dutch education system streams students into different educational tracks around the age of twelve as they enter secondary school (Van de Werfhorst and Van Tubergen, 2007). The tracking decision is generally based on both the scores of a test (called CITO) that students take in the last two years of primary school and the advice of the primary school teacher. While the test score is the most decisive element in the streaming decision (Luyten and Bosker, 2004), teachers can have an influential role in the choice of the educational stream by over- or under-advising (Hustinx, 2002). After streaming, students can attend a "bridge class" (brugclass) for one or two years, and are provided with an opportunity to change their track. Following the bridge year, students are directed towards one of the secondary education tracks, which are divided into three main streams with varying orientations, durations and levels of selectivity, subsequently providing access to distinct higher education opportunities. In contrast the French education system provides a comprehensive education until the end of lower-secondary school (collège), where the most critical selection occurs. At the last year of lower-secondary education, around the age of 15 , students are sorted into different academic and vocational trajectories. This process is called orientation, during which a class council (Conseil de classe) composed of teachers and school officials gather to make a streaming decision. Class councils consult the family and also take student grades into account, as well as the outcome of the Brevet des collèges or BEPC exams. After the rounds of consultation, the class council reaches a final decision against which parents hold the right to appeal (Durier and Poulet-Coulibando, 2007). As a result of orientation, students are streamed into two lyceum-based tracks; academic or vocational.

This tracking outcome has long-lasting consequences in the education of young people. Despite the early stratification process, the Dutch education system permits mobility between different tracks during secondary education and also provides later possibilities for upward 
mobility. In France, young people who are tracked into the vocational education are allowed to enrol in higher education if they acquire the baccalauréat professionnel. Nevertheless, the majority of young people seem to continue their institutionally pre-conditioned educational pathways. Tieben et al. (2010) using Dutch national data, showed that the majority of students pursue the educational trajectory they were initially streamed into, and only a minority switch tracks and achieve upward mobility. According to the TIES Survey in Amsterdam and Strasbourg, only $13 \%$ of the entire sample of native-born descendants of Turkish migrants in Amsterdam accessed university via the long vocational track compared $8 \%$ in Strasbourg (See Figs. 1 and 2 respectively).

\section{School choice}

Since young people also switch schools during the streaming period, the school choice is another domain where parents could have an influence on tracking. In the Dutch context, parents are given the freedom to choose their children's school (Karsten, 1994). In France, by contrast, parents are required to send children to a school in the postcode area (Mellottee et al., 2010). Nevertheless this restriction leads to the formation of ghetto schools in the suburban neighbourhoods, while native parents find alternative ways to manipulate their children's school choice via course selection or by sending them to private schools (Zanten, 1997). The choice of school among the parents primarily relate to their place of residence. In both Amsterdam (Karsten, 1994; Karstenet et al. 2003) and Strasbourg (Fabert and Raluy, 2002), a large proportion of immigrant families live in segregated neighbourhoods and attend local schools which reflect this population balance. Such schools are seen as an extension of neighbourhood ghettoization since most parents send their children to a "nearby" school (Karsten et al., 2003). In Amsterdam, 11 \% of students go to a school where the majority of pupils come from a non-Dutch background and in the old-west neighbourhoods, where most respondents resided, this percentage rises to 37 \% (Booi et al., 2009). In Strasbourg also, most respondents and their families resided in majority-minority neighbourhoods.

\section{Role of the parents}

In a recent study of the children of immigrants living in the Netherlands, Van de Werfhorst and Van Tubergen (2007) illustrate that neither the students' academic ability nor their tracking decisions are solely based on merit, but are rather dependent on the social class of the parents. As a result, even though tracking decisions are based on "merit", this is not in fact independent of children's parental background and home upbringing (Lauder et al. 2006). Bourdieu (1985) argues that one's educational talent- "merit"-is "itself a product of an investment of time and cultural capital" rather than a "natural aptitude" (p. 48). This investment is provided within the family habitus over time, though "the scholastic yield from the educational action depends on the cultural capital previously invested by the family" (p. 47). As a result, it matters a great deal what kind of cultural capital is invested in the family and how this capital is valued by the education system. In many studies, cultural capital is usually operationalized as having knowledge of highbrow culture and being able to manipulate the system to reproduce advantages (Van de Werfhorst, 2010). However, this operationalization is a rather limited understanding of the various 
ways in which parents could influence their children's education. For migrant parents with low educational background, we need a more open understanding of cultural capital to grasp how they support and shape their children's careers in different settings. There is a large body of literature in the United States on how migrant parents were able to affect their children's schooling (Louie, 2012; Zhou, 2005; Zhou et al. 2008). Migrant parents can transmit higher values of education to facilitate their children's upward mobility by enacting higher aspirations, which might stem from the sacrifices they made during migration or the yearning they have for upward social mobility (Louie, 2012; Zhou et al., 2008). They might for example rely on their prior human capital or the dense social networks within the community to enforce pro-educational values, as was evident in the case of Chinese migrants in the U.S. (Zhou, 2005).

In the case of France, Brinbaum and Kieffer (2010) have shown that French immigrant parents had higher aspirations for their children compared to native-born parents with similar educational and occupational backgrounds. Yet Schnell's (2012) study has shown Turkish migrant parents to have lower educational aspiration in France compared to Austria and Sweden. In the Netherlands, Crul (2009) showed that the aspirations of Turkish parents have improved compared to twenty to thirty years ago when they arrived (Bocker, 2000). This also points to the ways migrant communities are evolving over time, with each generation having distinct approaches to education.

In what follows, I will comparatively analyse how different educational structures provide room for parents to have an influence on their children's tracking outcomes, and also what kind of strategies the parents apply.

\section{Data and methods}

The current study focuses on the education systems of Amsterdam and Strasbourg since the cities are home to a substantial group of immigrants from Turkey and their descendants. Strasbourg and the wider Alsace region have a considerable Turkish population of 30,000 people, who form the dominant minority group in the area (Morel-Chevillet, 2005). In Amsterdam, the Turkish population is around 40,000 O+ S. (2012). Most of the Turkish migrants to both cities arrived via guest worker migration flows, and, as a result, both the descendants of immigrants are predominantly the descendants of guest workers (Bocker, 2000; Danış, D. and İrtiş, V 2008. Most parents migrated from Turkey around the same time and from similar regions and had lower educational and occupational status (Crul et al. 2012).

The quantitative information in the article draws on the Amsterdam and Strasbourg data of the TIES Survey, which is a cross-national survey with native-born descendants of immigrants from Turkey, Morocco and former-Yugoslavia and a comparison group of young people with native born parents in fifteen cities across eight countries (Groenewold, 2008). In both cities, the survey was conducted in 2008 with a target group of 18-35. TIES survey will be analysed to illustrate the tracking processes in both settings. Despite the indepth information it provides on the educational careers of the respondents, the TIES questionnaire did not survey the specific role played by the parents during the tracking decisions. As a result, qualitative interviews are utilized to address the underlying mechanisms during tracking decisions and the role played by parents. 


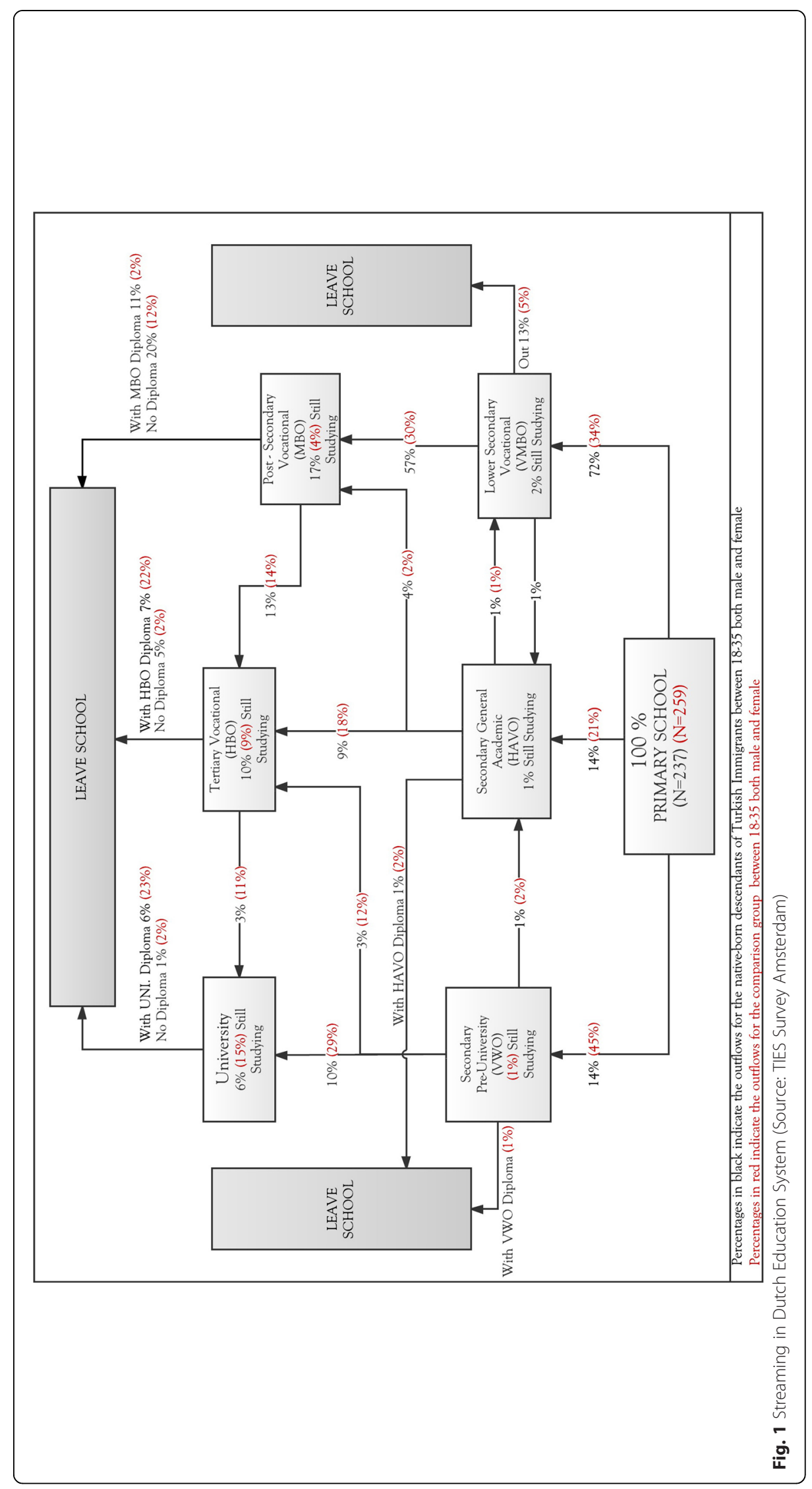




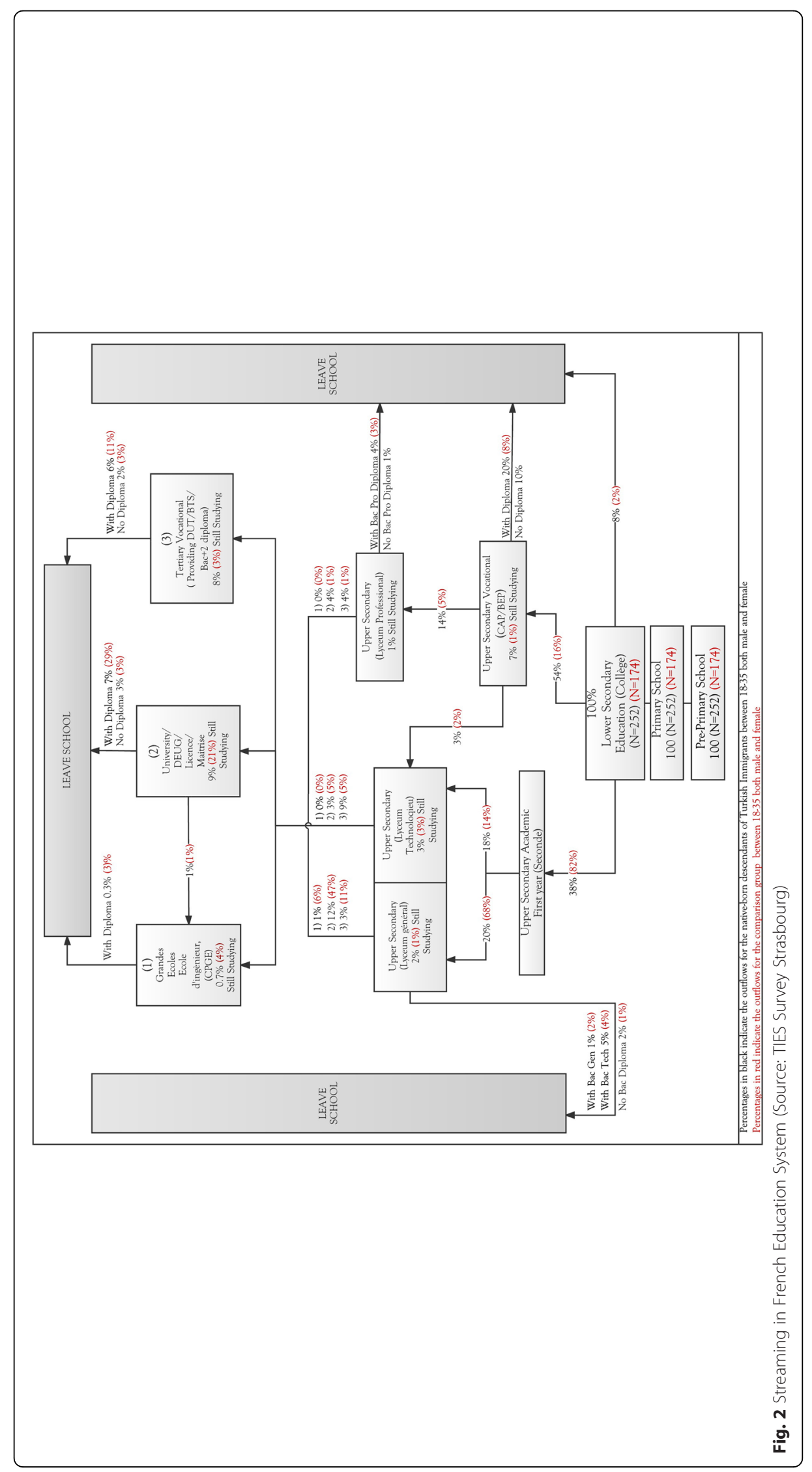


The qualitative data in the article is based on a fieldwork of fifty semi-structured, in-depth interviews with a sub-sample of the TIES Survey respondents in Amsterdam and in Strasbourg. The data was collected between years 2009 and 2010 from young people whose parents migrated from Turkey as guest workers or as the family members of guest workers. The majority of the parents had either low or secondary level education. The respondents were between twenty to thirty years old and a gender balanced was sought in both settings.

The current article mostly relies on the retrospective reflections of the young people on their past experience and the way they recall their parents' role. Clearly, the retrospective data reflects how the educational and labour market careers of young people evolved over time, and they mention regrets or evaluations which might have been different at the time of the tracking experience. Furthermore, the role of the parents is not based directly on the parents' accounts but rather on how young people look back on their parents' influence. However, since the study has a comparative stance, where young people with similar age, education level and parental background are juxtaposed, the effects of the subjective and retrospective information apply equally in both settings.

\section{Streaming in Dutch and French Education systems: Result from TIES survey}

To analyse the TIES Survey for streaming, flow charts were created from the Amsterdam and Strasbourg data sets. According to the TIES Survey data in Amsterdam, $72 \%$ of the descendants of immigrants from Turkey enter the lower secondary vocational track (MAVO) compared to $28 \%$ pursuing the secondary general-academic (HAVO) or secondary pre-university (VWO) streams (Fig. 1). According to the TIES data for Strasbourg, $54 \%$ of the descendants of immigrants from Turkey were directed to upper secondary vocational education, while $38 \%$ were oriented towards upper secondary academic lyceums, while some $8 \%$ had already dropped out of education during or after college (Fig. 2). The red numbers next to the black percentages in Figs. 1 and 2 illustrate the outcomes for children of native parents from France or the Netherlands. We see that, in both settings, the children of native parents access the academic track in higher numbers; 66 \% in Amsterdam and $82 \%$ in Strasbourg. This finding accords with the TIES research as a whole; even after controlling for the parental background, more second generation Turks were able to access the academic track in Strasbourg compared to those in Amsterdam (Crul et al., 2012). With regards to permeability, only $13 \%$ of the entire sample of native-born descendants of immigrants from Turkey accessed university via the long vocational track, compared to $8 \%$ who accessed university or BTS via the professional lyceum in Strasbourg (See Figs. 1 and 2 respectively). The following section will analyse the mechanisms behind the tracking decisions using data from the qualitative interviews. The qualitative data highlights differences across educational tracks as well as the different country settings.

\section{Streaming and parents: findings from qualitative interviews}

\section{Streaming and the role of the parents in Amsterdam}

Since the qualitative respondents were sampled from the TIES Survey, their tracking pathways demonstrated similarities. The majority of the respondents pursued the track that they were initially advised to, be it vocational or academic, but some students did modify their tracks during secondary education or later by prolonging their studies into higher education. Yet, irrespective of their tracking outcome, most respondents provide 
a similar discourse on tracking decisions in Amsterdam, attributing only a meagre role to their parents.

Academic track students in Amsterdam approved of the tracking decision, stating that the selection reflected their academic level. These students had high grades throughout their primary school education. They scored the highest grades in their classroom and school in the CITO test. For example, İsmail had first generation parents and he mentioned in the interview that his mother was illiterate. Ismail had already been spotted as a successful student by his teachers and had already been tracked into a class of highachieving children in his majority-minority primary school, which helped him get better grades in the CITO test. In Ismail's words, his parents "did not need to do much," but rather he was assisting them with language and other issues. His parents did not (or could not) play much part in his placement as they hadn't mastered the language or the rules of the educational field, but this was not problematized by İsmail since he was placed in the prestigious track by his teachers and he was happy with the outcome.

Almost all the participants in Amsterdam argued that their test score at the end of primary school (CITO) was the most significant determinant of their streaming. Also, students in the lower tracks, similar to the ones in academic track, argued that this test score reflected one's level or "capacity". Haluk's 1.5 generation (single) mother, who arrived in the Netherlands at the age of six, enrolled Haluk in a prestigious primary school populated mostly with children of native parentage to provide him with better educational opportunities, but Haluk was tracked into vocational stream. When asked, he associated "CITO results" with "capacity"

Interviewer: "What do you think about the stratification process at the end of primary school?"

Haluk: "I think it is good because they do a capacity test; they check your level. Can this boy or girl make it? Then comes the advice. I think CITO is most important; it shows what you (can) do."

Interviewer: "Do you think the selection is done well?"

Haluk: "I think so, because if it was like Turkey... I mean, whomever I ask in Turkey, they say they are doing academic lyceum. I ask myself-are these people that smart? Or is there no system?"

Turkey has a comprehensive education system with no tracking procedure. Haluk defines the role of (education) systems as sorting people into appropriate levels and states his confidence in the CITO test when determining students' levels. Gülden, the youngest child of first-generation Turkish migrant parents, was initially tracked into vocational education. She attended a neighbourhood school where the majority of the students were of immigrant background. After receiving her $\mathrm{MBO}$, she made a smooth transition into the labour market. Among her older siblings she is the only one who acquired any diploma:

Interviewer: "What do you think about the stratification process at the end of primary school?"

Gülden: "In fact, it is a good system, since everybody receives training at his or her own level."

Interviewer: "Do you think people are sent to right levels?" 
Gülden: "Well (pauses) I hear that students receive high grades but they are advised into lower tracks. I didn't experience anything as such. But still there is the Bridge year. You are given a chance to do HAVO (general-academic track) during this year. Interviewer: "What did your parents do during this (tracking) decision?"

Gülden: "Well they supported me of course but it's not like that you know, it's your grades, it's not your parents who decide for you to go."

Gülden underlines the two compelling institutional discourses in the Dutch education system: the first is that the streaming decision is based on one's (academic) capacity, and hence everyone is sent to their "own level" of education (also mentioned by Haluk); the other is that the system provides opportunities to switch tracks later. The pledge that students will always have the opportunity to prolong their studies and upgrade their trajectories if they improve their educational success over time is successfully transmitted by some teachers and it was mentioned by all of our vocationally tracked respondents. The restrictions of the structure as well as the varying motivations of the students were balanced by the discourse of flexibility embedded in the system. On the one hand, the premise of flexibility is committed to re-introducing "agency" into educational decisionmaking, and on the other emphasizes the agent's responsibility in shaping their educational career. Yet we know from literature that only a minority of the students were able to modify their tracking decisions later (Tieben et al. 2010). The strong emphasis on the role of the system also renders parents' intervention redundant, as becomes clear in Gülden's answer about the tracking decision being "not theirs to decide."

The third group of students are those who either wanted to or managed to modify their initial tracking decision. These students were more cautious about the merit of CITO tests, yet they also emphasised that the system did not provide room for parents to intervene in the decision. Sedat and Tuğba were able to make a transition from vocational to academic tracks (VWO and HAVO respectively) thanks to the advice of their primary school teachers, even despite their lower CITO grades. Tuğba's 1.5 generation parents had moved from the West to the East of Amsterdam so that she could attend a better school. Tuğba at first had difficulty catching up with rest of the students and couldn't score highly in the CITO test:

Tuğba: "Well my CITO was not so high but the teacher gave me a higher advice and sent me to the academic track (HAVO-VWO) bridge year. But if she was a bad teacher, she could also have sent me to a vocational track (MAVO), so I was lucky. The teacher in primary school is very important because they check your grades but also your advice. From there I pursued general academic track (HAVO)." Interviewer: "How about your parents, did they talk to the teachers about the decision?" Tuğba: "Oh no, well my parents always supported me you know, but no they did not interfere with the tracking decision: it's your grades and your teacher." Interviewer: "Do other parents do that?"

Tuğba: “No, I mean I haven't heard that. Maybe nowadays but not when I was young.”

As opposed to the first generation parents of Gülden and İsmail, Tuğba's 1.5-generation parents tried to assist her schooling by sending her to a better school, yet 
they did not take active part in the tracking decision. Sedat was also tracked into vocational education due to his CITO score, but then during the bridge year, thanks to his teacher's assistance, he was able to make a transition to the most prestigious academic track (VWO). When asked about his tracking outcome, while he was an economics student at university, he said "It's not like I chose between MAVO (secondary vocational education) or HAVO (secondary general-academic education); I was sent to MAVO because this was my level". Despite his modification and his subsequent success in the education system, Sedat initially interpreted his tracking decision as his level. In both Tuğba's and Sedat's cases, we see that it was their teachers rather than their parents who could play an active role in overturning the tracking decision.

The accounts of the respondents in Amsterdam illustrated that the CITO test and teachers' advice were the only means of determining their tracking. We also see that 1.5 generation parents tried to positively influence their children's education by sending them to better schools, yet none of our respondents mentioned their parents being able to have a direct impact on the tracking decision and explained this with the design of the education system rather than a lack of ability on the side of their parents. While the effect of parental background on tracking outcome is documented by quantitative studies (Van de Werfhorst and Van Tubergen 2007), there is hardly any qualitative study on whether middle or upper class native parents try to shape the tracking decision and if so how. The following section reveals striking differences with regards to the role played by Turkish migrant parents during the tracking process in Strasbourg, despite their similar educational and occupational status.

\section{Streaming and the role of the parents in Strasbourg}

In Strasbourg, the transition decision was primarily based on the grade point average (GPA) of the students during lower-secondary education (collège). However, in contrast to Amsterdam, the respondents also highlighted the role of their own motivations and their parents' guidance with respect to the tracking decision.

In respondents' accounts, all students had selected the institutions they would like to attend and this selection was evaluated by a class council based on their educational history in the institution. In the academic track, once more the high-achieving students made a direct transition into academic lyceum. Cem and Ayten had remarkably high grades throughout primary school and collège and were the highest achievers in their class. They both had first-generation parents who could only provide emotional support, but their educational success was already spotted by their teachers. Cem even skipped a year during primary school. During the orientation process, they were directly advised to attend a general lyceum. Both Ayten and Cem's parents played a marginal role in this process, since the tracking was already facilitated by their teachers and the school.

For students with an only average GPA, some of whom qualified for the academic track, the patterns were more mixed. One group of students had good grades and were also positively encouraged to take the academic track by their families. Hence already in Strasbourg the role of the family came to the fore, when discussing the tracking decision. Firat had first generation parents and he went to a neighbourhood school. His grades were average throughout college, and he was warned by his cousin at university to take the academic lyceum. 
Firat: "I studied in a banlieu school. I grew up there, in the HLMs. For that reason, my school was awful, it was full of gypsies, everything was bad about it. Then I went to secondary school (collège) in the same area. It was also quite bad. The class was full of Arabs and Turks. For high school, I was planning on going to a vocational lycée; my uncle's son was doing BEP there. When I started filling out my file, my cousin, my aunt's daughter, intervened and told me to go to general academic lyceum."

Interviewer: "How were your grades?"

Firat: "They were normal, I mean average; $12-13$. So I went into scientific lyceum because my cousin was studying medicine, I took the same pathway. She later got married and quit school, but I pursued the scientific lyceum and later entered university.

Interviewer: Would your cousin also help you with your homework?"

Firat: "Yeah, she would help me with French and history classes when I asked."

According to Firat, he would have chosen the vocational track if his cousin hadn't influenced his decision. Likewise, Selen and Sevgi were steered towards the academic track by their fathers, who were both well informed about the education system. Selen and Sevgi all had 1.5 generation parents, who were well acquainted with the higher prestige level of academic lyceum. Once they had eligible grades from collège, family members were there to assist them towards the academic track. Sevgi, who was a vocational tertiary school (BTS) student at the time of the interview, almost complained of her father's assertiveness with regards to academic lyceum.

Sevgi: "I also have a twin brother, and, since we went to collège, it was never in question that we would have to do (baccalauréat) général. My dad was obsessed about us going to university, and he knew the best way to go was through général (academic lyceum). He came here young, you know; he couldn't study because he couldn't speak French in the beginning. Now his French is great but he couldn't study enough. He has a good business and everything, but he wants us to study."

Given the existence of such cultural capital and motivation regarding academic track, the system in France provided space for parents (or relatives) to affect the tracking direction. Fahir's mother had arrived in France at the age of fourteen, developed proficiency in French, and was working in the Parliament as a cleaner. She and her husband wanted him to achieve better, so they sent him to a private school (college). Fahir had difficulty in his transition to academic lyceum and also later in finishing:

Fahir: "My mother always says you need to get the bac (baccalauréat referring to academic lyceum diploma); well everybody says that it's always bac! Then what? What do I do after? Anyway I am still struggling with my bac exams, but I don't know what I will do next."

While Fahir's experience of having 1.5 generation parents shows how they can help and even force their children to enter the academic track, their assistance was also limited in helping him to choose a direction. This lack of transparency was even stronger among vocational students. 
Among the vocationally tracked students, while the class council rejected the academic track selection of some of the students, other students preferred to take vocational tracks despite having grades eligible for the academic track. The latter case was never stated in the Netherlands, where test results and teacher's advice were the main determining factors. These students raised the various concerns that led to this decision. First, they weren't certain whether the class council would agree with their choices. Second, they were uncertain of the outcome of an academic track, and unclear whether, if they failed to win a place at university, they would still be able to enter a profession. In the end, many of these students opted for vocational lyceum (BEP). Most of these students expressed pro-work orientations. Boys in particular felt more pressured to learn a trade and earn their own income to become more independent. Ali was the ninth child of a first generation family. Hardly any of his older siblings had studied beyond vocational school. Even though he had very good grades in French during primary school, he didn't even consider studying in the academic track:

Ali: "My GPA was something like 13 or 14 [/20] at the end of collège."

Interviewer: "What was the decision of class council?"

Ali: "Well, they just review your (school) selections and they give a report of the

final decision. In my case, they said nothing because I had already chosen BEP in construction (vocational track) and they were OK with it."

Interviewer: "Why did you choose BEP construction?"

Ali: "Well I had heard about the job and liked it. And my grades, well, they were

OK, but I wasn't sure how far I could continue with them."

Interviewer: "Isn't 12 sufficient to access the academic track?"

Ali: "Well, I don't know, but also after général (academic lyceum) you have to

continue two to three years. I don't know, it was hard."

Interviewer: "What did your parents say?"

Ali: "Nothing. They said do what you want to do."

Ali's first generation parents had no proficiency in French and they weren't informed about the French education system. Ali also couldn't access such knowledge through his siblings and family, whom mostly worked in the construction sector so he was steered towards vocational school despite his eligible grades. According to students like Ali, the academic lyceum and the baccalauréat diploma were vague options that entailed uncertain outcomes after long studies or too much risk.

The third group of students went into vocational track but extended their studies into tertiary education. Having guaranteed the vocational diploma (BEP), these students moved into the next level to study for more diplomas. Şebnem had first generation migrant parents, who couldn't assist with her education. Even though a score of 12 was enough to attend an academic lyceum, she preferred to continue to vocational training:

Şebnem: "I wasn't a great student. My grades were average, 14-15 over 20. They weren't 18 or 19. I was just above average. But I was a good student, and had good relations with teachers. I could have gone to general lyceum, but I didn't want to because, you know, you make a direct transition to University. Back then I didn't think of University. Back then I thought a vocational degree would be sufficient, you 
know. But now it's different; the population grew, the degrees became less valuable. Back then I thought BEP would be enough for a good job. To earn a trade... The class council approved my decision, because everyone wanted to do a bac, they were happy that some people were choosing vocational study. A bit sneaky, right? They didn't warn me or anything"

A case like Şebnem's was also never mentioned in Amsterdam since the tracking decision was mentioned to be strictly based on grading rather than students' or parents' orientations. Şebnem's parents weren't involved with her tracking decision and she didn't have enough confidence to go into academic track and despite her eligible grades, and neither her teachers not the council directed her towards the academic track. Şebnem's case also shows how the room for orientation in the French system could initially lead to tracking below the level of students in the absence of parental assistance.

While the postulation of "meritocratic selection" dominated the discourses of respondents in Amsterdam, in Strasbourg the role of students' orientations and their parents' aspirations were part of the respondents' explanations for their tracking outcomes. Having a 1.5 generation parent or having a significant other who knows about the school system was directly reflected in the tracking decision in Strasbourg compared to Amsterdam even if the parents' resources were very similar. Those 1.5 generation parents who accumulated both linguistic competence and cultural capital about how the education system functioned and the significance of the academic track were able to steer their children towards the academic lyceums. Nevertheless, lack of transparency about academic higher education was an issue for both the 1.5 generation and other vocationally tracked students who pursued a vocational education despite their good grades.

\section{School choice and parents}

The accounts of the respondents showed that, while in Strasbourg parents had more direct influence on the tracking decision, in both settings some parents tried to influence the tracking decision of their children through their school choice. As mentioned, choosing a school is one of the ways parental advantage could be translated into young people's educational achievement (Karsten et al. 2003).

The interviews showed that one group of respondents' parents have developed a certain kind of cultural and linguistic capital by virtue of their earlier arrival in the Netherlands or France. These parents arrived in the immigration country as adolescents or teenagers and have been labelled the "1.5 generation immigrants" in the previous literature (Bocker 2000). The extra time spent in local educational and/or occupational institutions has helped these parents develop what Bourdieu, in a more general description of cultural capital, calls "information capital" (Bourdieu and Wacquant, 1992) (p.119). Although most of these parents are still not able to fully assist their children with their homework, they have acquired a good proficiency in Dutch or French and they possess information capital that distinguishes them from other parents with scarce language skills or scant conception of how schools or the labour market function.

The interviews showed that the common educational strategy of these parents was to send their children to prestigious schools with lower ethnic minority concentrations in order to facilitate better educational outcomes. Several examples of 
this experience were mentioned in the previous section both in the Netherlands and in France: Haluk's mother arrived in the Netherlands at the age of six, received vocational training and was working as a bus driver. Before Haluk started schooling, both his mother and her aunts researched the best schools in Amsterdam. Both of Tuğba's parents came to the Netherlands as twelve-year-old children, and moved from west to east Amsterdam hoping to provide better educational opportunities for their children. Ayşe's father, whose case we will discuss below, came to the Netherlands at age fifteen and studied here, sent her to a prestigious primary school in south Amsterdam. In Strasbourg, Fahir's mother arrived in Strasbourg at the age of fourteen since they lived in majority-minority neighbourhoods in which the schools had a majority of children of immigrants, they sent Fahir to private colleges. We will also discuss Ahmet's case, whose father arrived in Strasbourg at the age of thirteen and received some vocational training, and made arrangements to move to a village near Strasbourg with a prestigious school when Ahmet started his primary education.

In Amsterdam, despite the effort they put into the choice of their children's school, hardly any of the first or 1.5 generation parents were able to influence the streaming decision process. Having assured themselves that their children were in good schools, they displayed a rather conformist attitude towards the school's tracking decision. Ayșe's case illustrates what having 1.5 generation parents can provide, and also the limits of that cultural capital. Ayşe's father came to the Netherlands at the age of fifteen and received some schooling there. He has good proficiency in Dutch, and he works as a driving instructor. He sent Ayşe to a good (catholic) primary school where she could develop good language skills in Dutch. As she highlighted in interview, she has a "posh" Dutch accent; "I speak Dutch like those Istanbulite girls in the Turkish-TV series." In the CITO test, despite receiving the highest score in her class, making her eligible for the scientific academic track (VWO), she was sent one level below:

Ayşe: "Actually, I had the capacity for the pre-university academic education (VWO), but the teachers didn't see me as fit for it, you know, because they said that I had low concentration; I was too talkative. They were right. I am smart, but maybe I don't put my brain to good use (giggles). The general academic education (HAVO) was so easy; I got all my exams by barely studying."

Interviewer: "How was your CITO test?"

Ayşe: "It was the highest in my class. It was the pre-university education. I mean, I could have done it, but back then you didn't think of these things. I was twelve or thirteen, you know."

Interviewer: "How about your parents?"

Ayşe: "Well, they were happy that I was studying at all. I would just stop by my parents at the end of each year. They weren't really (involved), you know."

Thus, despite their efforts with respect to her school choice, the prestige difference between the academic tracks went unnoticed by Ayşe's parents, and they did not interfere with her tracking decision. As she mentions, she was clearly eligible to study in the most prestigious scientific track. At the time of the interview, she was finishing her $\mathrm{HBO}$ degree and she was considering pursuing a pre-master and then an MA degree. 
In Strasbourg, Ahmet's father had sent him to a prestigious village primary school hoping it would provide better educational opportunities. In fact, the family moved to the village in order to escape the schools in the suburbs. Ahmet's uncle assisted with external supplemental courses, and he ended up going to a general lyceum. After receiving his lyceum diploma (baccalauréat général), Ahmet went to university to study public administration, since this was what all of his friends were doing. He discussed his educational choices:

Ahmet: "Well, anybody can go to university. There is no problem there. As long as you have a bac diploma of course. But, you know, they have a hidden system. Of course, a university diploma is not bad; it shows that you have a certain level of education, as well as a certain cultural standing. But, you know, there are these schools where the statesman and MPs attend."

Interviewer: "You mean the Grandes écoles?"

Ahmet: "Yes, exactly. For example, in Strasbourg there is one famous one; ENA. I mean, for people like us, it is impossible to enter these (schools).

Interviewer: How so?"

Ahmet: "Well, our parents came here as immigrants. My grandfather came here first. My father was thirteen when he came. He did vocational school here. He speaks very good French. He started his own business, and he achieved a lot. I mean, he does everything for his family and his kids. He moved the entire family to this village because there are better schools there. But it's my mum who was at home, raising us, and she speaks no French. I mean, at home we all speak Turkish. Yeah, we went to school, back and forth, but we achieved everything on our own. University is as much as we can achieve. For our kids, it will be different, since we know about these schools now. During lyceum, I wasn't even aware that they existed. After I found out, I considered trying, but then I thought it would be too difficult."

Ahmet emphasizes how the generational differences were translated into his educational trajectories and his father given his knowledge has done his best to provide his family with good opportunities. We have seen that some immigrant parents do possess some cultural capital with respect to how the education system functions, even though the composition and magnitude of this capital is rather limited. Furthermore, the role of parents with comparable levels of cultural capital varied significantly across settings based on the rules of the field: in Amsterdam, parents' role was limited to school selection, while in Strasbourg, the parents were more able to manipulate the orientations of their children and the decisions of the school during the streaming process at the end of college.

\section{Conclusion}

Bourdieu underlines both covert and overt forms of differentiation in education. This study illustrated the experience of descendants of Turkish migrants of these mechanisms and explored the role played by their parents in key educational decisions.

TIES data was used to illustrate that majority of descendants of immigrants from Turkey were streamed into vocational tracks in Amsterdam and Strasbourg, and only a 
minority managed to modify their initial track. More respondents accessed the academic track in Strasbourg, while intra-trajectory movements were slightly higher in Amsterdam.

The qualitative interviews inquired how descendants of migrants from Turkey reflected on their tracking decision. In addressing the question of merit and cultural capital during the early tracking, it has been illustrated that, while young people in Amsterdam are tracked into the vocational track in higher numbers, the respondents attributed their streaming outcomes to the national test scores rather than their own motivation or their families' preferences. According to the respondents, families seemed to have very little influence on the transition decision due to the restrictions of the system. Clearly this does not mean the parents do not have any role at all. In fact some parents already tried arranging schools for their children to increase their chances of achievement. Nevertheless the education system is designed in such a way that the parents of the respondents in this study were not able to have a direct impact on the tracking outcome.

In Strasbourg, however, the tracking decision was a result of a combination of students' grades, their own orientations, and their family's aspirations. Respondents highlighted cases where parental aspirations for academic training or the advice of an informed member in the family could reverse or influence their tracking decision. This is not to claim that parental involvement only functions in this way, but when it does it makes a difference for young people to have informed parents. This also does not mean the parents and the respondents in Amsterdam are less informed about the returns of the academic track. On the contrary, in Amsterdam all the respondents attributed prestige to the academic track, did not question its returns with regards to transparency, and articulated their lack of participation with their own meritocratic failure. Some vocational-tracked students also tried to prolong their studies in order to improve their chances in the labour market. However, in Strasbourg, some students who had eligible grades to access academic stream preferred to pursue a vocational track, and the school authorities approved this decision. The tracking choices of these young people were partly because of low study motivation or lack of parental steering but were also strongly related to their perception of French lyceums. These were discerned as lacking any occupational orientation and thus as unable to guarantee high returns in either tertiary education or the labour market. Such cases were not encountered in Amsterdam. This might also serve as an interesting explanation for the results of recent studies that report the "under-performance" of descendants of immigrants from Turkey in France compared to other second-generation groups and children of natives (Brinbaum et al. 2012). Hence, low parental aspirations and issues of orientations could be one issue leading young people in Strasbourg to despair of higher education. This argument also corroborates the importance parental aspirations in understanding educational outcomes in France (Brinbaum and Kieffer, 2010).

With regards to role of parents, different settings are differentially responsive to forms of parental support and the meritocratic achievements of young people. In the case of Amsterdam, parental support was limited, but future studies could look into how parents, be they migrant or native, can influence tracking decision indirectly by helping their children achieve higher CITO scores while making sure they are sent into the level they have earned through the exam. The strategies of middle or upper class 
native parents could help reveal the covert mechanisms of tracking in the Netherlands. In Strasbourg, parents who had similar informational capital and aspirations for academic education could make a difference for their children's tracking decision, since the system allowed it. As a result, we can argue that the receptiveness of the French education system to parents' information capital with regards to the tracking decision could be one more factor that explains the increased number of students in the academic track in Strasbourg compared to Amsterdam, next to all the other factors cited in the literature (Crul et al., 2012). Nevertheless, whether parents could provide instrumental guidance for their children should be further scrutinized in future studies seeking to understand young people's educational experiences.

These findings highlight the importance of more in-depth study of parents' orientations and practices in order to understand the tracking outcomes of young people. Generational differences and levels of information and cultural capital about the education system are crucial factors with which parents can influence their children's tracking decisions. However, these characteristics should be scrutinized within the structural conditions of the education systems and the amount of room they provide for parents' intervention.

Competing interests

The author declares that she has no competing interests.

\section{Authors' contributions}

EK carried out the qualitative study, analyzed the TIES survey and drafted the manuscript.

Received: 20 March 2014 Accepted: 10 February 2015

Published online: 01 October 2015

\section{References}

Allmendinger, J. (1989). Educational Systems and Labor Market Outcomes. Eur. Sociol. Rev., 5(3), 231-250.

Böcker, A. (2000). Paving the way to a better future. Turks in the Netherlands. In H Vermeulen \& R Penninx (Eds.), Immigrant Integration. The Dutch Case (pp. 153-177). Amsterdam: Het Spinhuis.

Bol, T, \& Van de Werfhorst, HG. (2013). Educational systems and the trade-off between labor market allocation and equality of educational opportunity. Comp. Educ. Rev., 57(2), 285-308.

Booi, H., De Jong, I., Oirschot, L. \& Slot, J. (2009). De Staat van de Jeugd, [The city of the Youth]. Jeugdmonitor [Youthmonitor]. Amsterdam 2009. Retrieved from http://www.ois.amsterdam.nl/pdf/2009_staatvandejeugd.pdf

Bourdieu, P. (1985). The forms of capital. In JG Richardson (Ed.), Handbook of Theory and Research for the Sociology of Education (pp. 46-58). New York: Greenwood.

Bourdieu, P. (1999). The weight of the world: social suffering in contemporary society. Oxford: Polity.

Bourdieu, P, \& Wacquant, LJ. (1992). An invitation to reflexive sociology. Chicago: University of Chicago Press.

Brinbaum, Y, \& Kieffer, A. (2010). Trajectories of Immigrants' Children in Secondary Education in France: Differentiation and Polarization. Popul. Engl. Ed., 64(3), 507-554.

Brinbaum Y., Primon J.L., Moguerou L., 2012, Les enfants d'immigrés ont des parcours scolaires différenciés selon leur origine migratoire, In. Immigrés et descendants d'immigrés en France - Insee Références - Éd. 2012. 43-49.

Brunello, G, \& Checchi, D. (2007). Does school tracking affect equality of opportunity? New international evidence. Econ. Policy, 22(52), 781-861.

Crul, M. (2009). Educational Progress of Children of Turkish Descent in the Netherlands. International Journal on Multicultural Societies, 11(2), 195-211.

Crul, M, \& Schneider, J. (2010). Comparative Integration Context Theory: Participation and Belonging in New Diverse European Cities. Ethnic and Racial Studies, 33(7), 1249-1268.

Crul, M, Schneider, J, \& Lelie, F. (2012). The European second generation compared: Does the integration context matter? Amsterdam: Amsterdam University Press.

Danıs, D, \& Irtis, V. (2008). Entegrasyonun ötesinde Türkiye'den Fransa'ya göç ve göçmenlik halleri. [Beyond Integration; phases of being a migrant and migration from Turkey to France] (Vol. 210th ed.). Istanbu: Istanbul Bilgi Universitesi Yayınları.

Durier, S, \& Poulet-Coulibando, P. (2007). Formation initiale, orientations et diplômes de 1985 à 2002 [Initial schooling, orientation and graduates from 1985 to 2002]. Économie et Statistique, 74, 143-159.

Fabert, J, \& Raluy, P. (2002). Quel developpement urbain pour Strasbourg?: Alsace. [Which urban development for Strasbourg?]. PCM le pont, 100(8-9), 19-21.

Groenewold, G. (2008). Sample design, survey implementation and evaluation. In M Crul \& L Heering (Eds.), The position of the Turkish and Moroccan second generation in Amsterdam and Rotterdam. The TIES study in the Netherlands. Amsterdam: Amsterdam University Press. 
Hustinx, PWJ. (2002). School Careers of Pupils of Ethnic Minority Background After the Transition to Secondary Education: Is the Ethnic Factor Always Negative? Educ. Res. Eval., 8(2), 169-195.

Karsten, S. (1994). Policy on ethnic segregation in a system of choice: the case of the Netherlands. Journal of Education Policy, 9(3), 211-225.

Karsten, S, Ledoux, G, Roeleveld, J, Felix, C, \& Elshof, D. (2003). School choice and ethnic segregation. Educational policy, 17(4), 452-477.

Lauder, H, Phillip, B, Dillabough, J, \& Halsey, AH. (2006). Education, globalization, and social change. New York: Oxford University Press.

Louie, V. (2012). Keeping the Immigrant Bargain: The Costs and Rewards of Success in America. New York: Russell Sage.

Luyten, H, \& Bosker, RJ. (2004). Hoe meritocratisch zijn schooladviezen? [How meritocratic are the school advises?]. Pedagog. Stud., 81(2), 89-103.

Mellottée, Laetitia, Becquet, Valerie, Danic, Isabelle, Lepape, Marie-Clémence; Leroy, Philippe; Loncle, Patricia; Muniglia, Virginie (2010): Governance of Educational Trajectories in Europe: Country Report France. Rennes: School of Higher Studies in Public Education.

Morel-Chevillet, R. (2005). Immigrer en Alsace. [Migration to Alsace]. Population, 30, 8-9.

Mueller, W, \& Gangl, M. (2003). Transitions from Education to Work in Europe: the Integration of Youth into EU Labour Markets. Oxford: Oxford University Press.

( OiS 2012 p.24). Amsterdam in cijfers 2012. Retrieved from Alternative URL: http://www.ois.amsterdam.nl/pdf/ 2012\%20jaarboek\%20amsterdam\%20in\%20cijfers.pdf

Schnell, P. (2012). Educational Mobility of Second-Generation Turks. Amsterdam: Amsterdam University Press.

Tieben, N, De Graaf, PM, \& De Graaf, ND. (2010). Changing effects of family background on transitions to secondary education in the Netherlands: Consequences of educational expansion and reform. Research in Social Stratification and Mobility, 28, 77-90.

Tieben, N, \& Wolbers, M. (2010). Success and failure in secondary education: socio-economic background effects on secondary school outcome in the Netherlands, 1927-1998. Br. J. Sociol. EduC., 37(3), 277-290.

Van de Werfhorst, HG. (2010). Cultural capital: strengths, weaknesses and two advancements. Br. J. Sociol. Educ., 31(2), 157-169.

Van de Werfhorst, HG, \& Mijs, JJB. (2010). Achievement Inequality and the Institutional Structure of Educational Systems: A Comparative Perspective. Annu. Rev. Sociol., 36, 407-428.

Van de Werfhorst, HG, \& Van Tubergen, F. (2007). Ethnicity, schooling, and merit in the Netherlands. Ethnicities, $7(3), 416-444$.

Zanten, A. (1997). Schooling immigrants in France in the 1990s: success or failure of the republican model of integration? Anthropol. Educ. Q., 28(3), 351-374.

Zhou, M. (2005). Ethnicity as social capital: community-based institutions and embedded networks of social relations. In GC Loury, T Modood, \& S Teles (Eds.), Ethnicity, Social Mobility and Public Policy in the US and UK. NY: Cambridge.

Zhou, M, Lee, J, Vallejo, JA, Tafoya-Estrada, R, \& Xiong, YS. (2008). Success Attained, Deterred, and Denied: Divergent Pathways to Social Mobility in Los Angeles's New Second Generation. The ANNALS of the American Academy of Political and Social Science, 620(1), 37-61.

\section{Submit your manuscript to a SpringerOpen ${ }^{\circ}$} journal and benefit from:

- Convenient online submission

- Rigorous peer review

- Immediate publication on acceptance

- Open access: articles freely available online

- High visibility within the field

- Retaining the copyright to your article 